\title{
PRE-WAR FORESTRY AND LUMBERING IN CZECHOSLOVAKIA ${ }^{2}$
}

\author{
By LEON I. KOERNER
}

I HAVE TO SAY that I feel quite embarrassed to have been called on to speak before such an illustrious audience on the subject of "Pre-war Forestry and Lumbering" in my native country, Czechoslovakia. My embarrassment is caused by two facts. In the first place I feel that my knowledge of the English language with its many (for a stranger) extremely difficult intricacies, is too limited to enable me to speak with the fervor necessary to make a lecture well sounding and interesting. Secondly, hecause of lack of any figures on which to base my enunciations, I have to reduce them to generalities which may not stand up to scientific criticism. I hope my apologies before starting will influence your kind indulgence.

$U_{p}$ to the time of Stevenson's invention of the locomotive and the introduction of rail traffic, practically all European forests were virgin forests and the lumbering was on a locally limited and small standard.

Easy accessibility and varying demand for house building purposes, decided exclusively on depletion of woods. Only those forests around then the world water trade routes, were depleted, mostly for ship building.

Thus, in the sixteenth and seventeenth centuries, the Venetian and Genoese free traders slaughtered down the huge forests around the Mediterranean and Adriatic sea shores, and the Hanseates (free traders from Hamburg, Bremen and Lubeck), the southern shorelines of the Baltic. No regard was taken to reforestation and stone deserts in the south and sand deserts in the north, still are witness of the crimes then committed against nature.

The huge virgin forests in all Europe up to the middle of the nineteenth century were practically worthless and no care for their upkeep and maintenance was taken. No wonder that by fire, disease, and windfall, destruction and distortion were very considerable.

The picture changed quickly as soon as Europe was opened up by a rapidly growing net of railways. Not only because the forests became accessible but also that the demand for wood and wood products for the construction of railways and the erection of many new towns and villages, was considerably increased. Quite new industries grew like mushrooms to never expected extent. The introduction of steam power created an extraordinary expansion of industries all over Europe even in the smallest Godforsaken places.

The lumber industry had to undergo an entire change. In the place of small water mills, new, giant (relatively to the size of logs) steam-driven sawmills were erected, equipped with new, quicker and more exact producing machinery.

1 Address to a meeting of the Vancouver section of the Canadian Society of Forest Engineer held at Brock's Memorial Building, University of British Columbia, February 21, 1944. 
Experienced lumbermen from Sweden and Northern Germany were attracted by the chances which opened up, but also many, more or less unscrupulous, speculators from all parts of the Continent infiltrated the wooded areas and a wild buying of timberlands and licences took place. Anybody was able to sell any amount of lumber he undertook to produce, and sell it at a very good profit. So you can imagine what the boom was like during, say, the 1840's and up to the 1870's.

The forests were the sacrifice to the money-making. They were depleted at an appalling rate without any thought for posterity. Only those stands whose accessibility was connected with high cost investments, were spared destruction.

As soon as an area was depleted, after a few years of complete devastation, the industry moved to another place and ghost towns and villages remained as a bad souvenir of a very bad period.

To avoid complete destruction the Governments had to interfere and in all countries new strict forest laws and forest jurisdiction was started. The principles were, in all countries, more or less the same although they differentiated according to circumstances. They were:

A. Planning and regimentation of depletion of wooded lands on the basis of annual regrowth, to guarantee a continuous and sustained yield.

$B$. The annual depletion to be made in sections, so as to prevent damage to vast area from excessive windfall, snow and floods (in spring from thaw and in summer through sudden and heavy rain storms) and also to enable the surrounding seed to regenerate new growth and further to preserve wild life and fishing.

C. Reforestation through regeneration and replanting, thus that the right kind of forest should regrow to obtain best commercial value of the regrown product. Regard was to be taken to the best suitable soil, most favourable geographical situation, to altitude, light and wind conditions or in short, to regrow as quickly as possible the most valuable forest. The idea was not to leave it any longer to nature alone to help itself, but to aim to help nature scientifically to reproduce in the right place, the right tree under best possible conditions.

D. Provisions were made continuously to survey and watch the growing forest and eliminate obstacles which should interfere with quick and best development and also eliminate constantly, any mistakes observed during any one period of growing.

E. Ruling for prevention of, and protection against, fire and any contagious diseases.

F. Regimentation of tourist traffic, mushroom and berry pickers, grazing of cattle and sheep and strict rules for hunting and fishing.

G. Exact ruling for the supervision by educated and trained forest personnel.

Parallel with the introduction of these forest laws and especially with reference to the last mentioned question of personnel, high school and university education for rangers and foresters were brought into operation. 
The most famous schools in Europe became the Forest Colleges of Eberswalde, Tharandt and Munich, in Germany; the Hochschule Fuer Bodenkultur in Vienna, and Vysoka Skola Lesotechnicka in Brno, Czechoslovakia.

The forests in Europe were partly State forests and partly privately owned. For both, all regulations were alike. Both State and private forests came under the supervision of respective departments of the Ministry of Lands and Forests. (I wish to mention that the chief foresters were only in charge of the management of the State Forests and had entirely nothing in common with the Control Departments.)

It took many years to build up the organization for private and govern. mental supervision of forests and for the education and organization of forest personnel. A long time since of course, it developed perfectly well and came into working channels smoothly and satisfactorily and it was recognized by everybody as being beneficial for the respective countries.

The organization of forest personnel into hundreds and thousands of local, national and international associations for the purpose of economical and social co-operation has been completed gradually and it would take me a full evening to speak of all that has been achieved in this direction. One thing which I do want to mention in this connection, however, is the establishment of permanent bodies, financially well equipped and permanent. ly subsidized by the respective governments, who scientifically, nationally and internationally looked after forest research, research of fish and wild life, propaganda by literature and films, organization of regular exhibitions, congresses and so on.

Close co-operation and solid understanding was permanently established between all these organizations and all other organizations of forest product industry and all connected with them such as: lumber industries, pulp and paper industries, mining, wood chemical industries, construction industries, architect organizations and so forth.

On October 28, 1918, as the result of the breakdown of the AustroHiungarian Hapsburg monarchy, of which she was part up to then, for over 300 years, the Czechoslovakian Republic took over the heritage, good and bad, with all the great assets but also with the many deeply anchored liabilities.

It was the genuine endeavour of the new country's enthusiastic leaders to maintain the good in every respect, and make it better, and to improve the bad and bring it up to good. Anybody who had the chance to see, watch and judge, unbiased, what has been done during the 20 years of Czechoslovak independence, had to admit that wonderful results have been achieved and miracle-like changes accomplished in spite of the too short period of only 20 years and in spite of the many obstacles which stood in the way of quicker development.

Czechoslovakia was, up to the last minute of her pre-Munich existence, an absolute democratic country ruled by the will of its hard working, intelligent and well-educated people, through the machinery of a well-trained and reasonable bureaucracy. 
She was the only one of all Central European countries without inflation as an aftermath of the last World War, in solid financial standing, with a strike-free development of extensive labour rights, with excellent international connections and relations and (because mutually co-operative) very flourishing agriculture and industry.

With pride I also speak of Czechoslovakia's forest and forest industries.

About one-third of the 140,000 square kilometres of Czechoslovak territory, a total of about 12,000,000 acres, was wooded lands- 55 per cent of it coniferous, 30 per cent deciduous and 15 per cent mixed.

The commercial species were: a kind of white spruce by the Latin name of Picea excelsa; a type of pine with the Latin name of Pinus silvestris; the larch by the Latin name of Larix Europea; the oaks with the Latin names of 2uercus pendunculata and 2uercus sessiliflora; the beech known by the Latin name of Fagus silvatica and the maple by the Latin name of Acer pseudoplatanus (not to be mistaken with the Canadian Sweet Maple Acer Saccharinum.)

The yearly growth was, at a conservative estimate, about $18,000,000$ cubic metres, equivalent to about four and a half billion feet. The yearly depletion never reached full regrowth as! the forest policy aimed to create reserves. The average depletion ran between 14 to 17 million cubic metres per year. About 80 per cent to 90 per cent of all forest products were used on the domestic market. Only 10 per cent to 20 per cent, depending on domestic demand and tendency of price, were exported.

The customers were Germany, Hungary, Holland, Belgium, France, Switzerland, and England. Small quantities went to South Africa and. South America.

There were practically no more virgin forests left in Czechoslovakia; all were second growth forests, the oldest being just over a hundred years. Practically all forests were fully accessible and very well-looked after. The impression one had, walking through a Czechoslovakian forest, was of a walk through a well-cleaned park.

The ownership was about $1 / 3$ State, $1 / 3$ Municipalities, Universities, and the different Churches, (though mostly the Catholic Church) and $1 / 3$ privately owned.

The State forests were partly taken over from the ex-Austrian-Hungarian state property; partly by confiscation of the property of the outlawed Haps. burg family, and they were also partly acquired by purchase from large land owners mostly of German-Austrian and Hungarian aristocratic families. A law was established that anybody who possessed more than about 2,000 acres had to sell the remainder to the Ministry of Lands at a thoroughly-assessed fair price. This acquired property was either sold in small lots to the farmers, returned soldiers, Municipalities or co-operatives, or incorporated en bloc into the State Forests. More than 6 million acres of such property has been acquired from about 1,700 owners, $1 / 2$ of it forest and $1 / 2$ of it agricultural land and distributed to more than 300,000 individuals. 
Thus, not only forests but also sawmills, timber preserving plants, box factories, veneer plants and agricultural industries, breweries, sugar factories, distilleries and so on, came under the management of the Chief Forester and, respectively, his agricultural deputy.

The Chief Forester, a civil servant in the rank of State Minister, and his agricultural deputy, had the responsibility of their respective Depart. ments, which were organized on a purely commercial basis. Long.term agreements with leading private firms in the respective lines were made for the best utilization of all products.

Several limited companies with the majority of share capital under government control, operated the production and selling end of the business, 100 per cent on the principle of private enterprise, with the purpose to bring highest possible returns to the State Forests. All returns were used ex. clusively for maintenance, upkeep and improvement.

It is easy to understand that the State Forests as the largest single operator in the production, sale and export of wood products, played a most important leading role:

A. In all labour questions;

B. In the establishment of prices on the home market;

C. In all international agreements aimed at the stabilization of prices and conditions on all world markets.

The private industry and all the rest of the other forest owners were glad to co-operate.

Logging and lumbering was adjusted to the ruling forest laws which, with necessary changes and improvements, remained those of pre-war Austria-Hungary.

The handling of trees not over 100 years old does not necessitate the heavy equipment without which this Coast just could not do, as long as giant virgin trees have to be moved and operated on.

Labour costs were very much lower than anything paid on this continent. Therefore, in forests and industries very much more labour was occupied and practically no machinery, except truck and rail equipment for trans. portation and mill machinery, was used.

The small individual areas, allowed for annual depletion, made every middle-sized logging operation stretch out over very considerable distances and necessitated the employment of local farm labour. No expensive permanent or half-permanent camp buildings with luxurious cook houses were necessary or possible. Most primitive accommodations and nutrition was the rule for the men in the woods during the relatively short working period.

All work in the woods was piece work, based on cubic measurement, and woods work was considered as seasonal work. Only in very limited localities was logging a year round operation.

In April, early May, the fallers started to work followed by bark peelers, 
who cut the bark for tanning and at the same time for prevention of the worm attacking the log. Only the tops of the trees were unbarked, to allow the sap to expire in the most natural way. Wherever possible, the tree was left in full length of from 30 to 80 feet. Bucking was an exception and performed only at the mill site.

The tree dried during the next months and its handling became so much easier in late summer.

During July-August the preparations for the hauling were made, chutes were built in soil and of wood.

In September-October, with the first morning frosts, the chuting started down to the creeks and at the same time the winter felling started, close to the creeks.

December to February the hauling with sleighs and horses to the main valley, to the truck road or railroad, was performed. There the logs were piled up for months long storage and from there the regular transport to the mills took place all year round. There was no slash burning.

In April-May of the following year the cordwood worker came and produced pulpwood for the pulp mills and so-called firewood for chemical use. Practically nothing remained unused.

The following spring the branches were gathered by the school children and the necessary re-planting then took place.

The mills were, in comparison with what we have in this country, small, sized mills. The largest mill in Czechoslovakia would not produce more than 20 million feet per year. Most of the mills produced between 1 and 5 million feet only. The territory of the lumber mills was very much more extended, because of the necessity of grading logs in front of the mill and because of the amount of air drying of the lumber produced.

The equipment of the mills was small and slow to enable very careful operation at a minimum of waste. Gangs, resaws, pony edgers, rip saws, and planers, constituted the normal mill outfit. The capital expenditure was comparatively low, mechanical equipment was substituted by cheap manual labour.

The principle of cutting was to cut the lumber to what the log contained and not to cut the log to an existing order file. All the lumber produced was air or kiln-dried. Sheds for protection against the weather for storage and loading were a normal sight.

Good labour management relations were on a more or less patriarchal basis, in spite of Nation-wide Union recognition. Wages were low but standardized and a national scheme for security of life of the working class. es was general.

Each production had its own established and registered trade mark and the selling was based on individual treatment of markets and customers.

It would mean a further abuse of your patience should I now, in coming to the close, give you a detailed outline of the International trade co- 
operation of the united Czechoslovakian forest products industry. I do wish to mention, however, before closing, that Czechoslovakia was an active member, from the very foundation of the C.I.B. (Committee International de Bois) with head office in Vienna and later in Brussels and of the E.T.E.C. (European Timber Exporters Convention) with headquarters in Stockholm, Sweden.

The aim of the C.I.B. was wood research, lumber trade statistics and trusteeship for bi-lateral or multi-lateral international trade agreements. Twenty-six nations participated in the very aggressive and successful activity of this International body created in 1930 by the initiative of the League of Nations in Geneva.

The E.T.E.C., created in 1933 in Copenhagen, was the softwood quota cartel of nine European lumber exporting countries, representing in total, 97.7 per cent of all lumber exports from Europe. The following countries took part in the E.T.E.C.: Soviet Russia, Finland, Sweden, Latvia, Poland, Rumania, Yugoslavia, Austria and Czechoslovakia.

Each country, through three delegates, elected or nominated by their respective Governments from year to year, accepted and guaranteed to a certain maximum export quota for their respective countries, always for the period of one year. Thus the offer and demand on all world markets was controlled and equalized and a considerable stability of price achieved.

Through Nazi aggression these two useful International organizations ceased to exist in 1939 and since that time also my native land has had to suffer subjugation by the Nazi hordes.

Little is known to me what crimes the Nazis committed to the country, its people and its forests and their industries. One thing I know, that wood and its products have already played a most important part in Germany's war preparations. They used it (beyond what we would call the normal use of wood) for automotive fuel, chemicals of all kinds, feed for cattle, sugar production, manufacture of fibre in any form, plastics, synthetic rubber and hundreds of other things never before dreamed of as derivatives from wood.

War needs will certainly have improved their methods and considerably increased the variety of uses. Czechoslovakian forests, as well as those in other occupied countries, will have to pay the bill.

I hope with you and with the hundreds of millions of suffering people in the world, and especially in Europe, that their ordeal may end soon, by complete Victory for the United Nations, and that liberation and peace may bring happier days for all and for evermore. 